Anna Walczak

Uniwersytet Łódzki

\title{
Tworzenie wiedzy pedagogicznej z perspektywy archetypowych wymiarów kobiecości i męskości
}

Podmiot jest caty czymś.

M. Merleau-Ponty

\section{W kierunku nieświadomości jako zapomnianego wymiaru tworzenia wiedzy pedagogicznej}

Jeśli uznać, że z jednej strony wiedza ma dawać orientację w pedagogicznym działaniu i orientować to działanie, z drugiej, że jest ona rodzajem doświadczenia, które nabywa się w praktyce komunikacyjnej (dialogicznej, ukonstytuowanej w dialektyce pytania-odpowiedzi), to można ją samą rozpatrzyć w trzech aspektach. Po pierwsze jest wiedzą o nas samych i o świecie, wiedzą, dzięki której „jakoś” siebie i świat rozumiemy - „jakoś” rozumiemy świat pedagogiczny i podmioty obecne w tym świecie. Można ją zatem określić jako wiedzę antropologiczną. Po drugie jest wiedzą, w której zawiera się nasz stosunek do świata pedagogicznego i do jego podmiotów, ustanawiający ich sens. Byłaby to wiedza aksjologiczna i teleologiczna, źródłowo zakorzeniona w tego typu pytaniach, jak np. „dlaczego?”, „po co?”, „w jaki sposób?”. Dwa powyższe aspekty wiedzy pedagogicznej sumarycznie tworzą wiedzę, którą określę jako wiedzę kontemplacyjną, budującą się w procesie refleksji nad praktyką i w praktyce ${ }^{1}$. Wiedza pedagogiczna jest zarazem wiedzą praktyczną, ponieważ jest wiedzą „działającą w praktyce". Jak to można rozumieć? Przede wszystkim jest to wiedza odnosząca się do sfery działań ekstra- i interpersonalnych, które stanowią meritum wszelkiego

\footnotetext{
Por. R. Kwaśnica, Wprowadzenie do myślenia o nauczycielu, [w:] Pedagogika. Podręcznik akademicki, pod red. Z. Kwiecińskiego i B. Śliwerskiego, t. II, PWN, Warszawa 2007; A. Walczak, Od refleksji do bycia refleksyjnym pedagogiem, [w:] taż, Spotkanie z wychowankiem. Ku tożsamości ipse pedagoga, Wydawnictwo Uniwersytetu Łódzkiego, Łódź 2011.
} 
działania pedagogicznego ${ }^{2}$. Pedagogiczna wiedza praktyczna nie jest odzwierciedleniem zewnętrznej wobec niej rzeczywistości pedagogicznej. Jej praktyczność odsłania i generuje nowe jakości - wartości i sensy tejże rzeczywistości.

Wiedzę pedagogiczną w ujęciu trzyaspektowym można potraktować jako paradygmat działania pedagogicznego. Byłaby ona wówczas narzędziem, za pośrednictwem którego można spostrzegać-poznawać-rozumieć-interpretować-tworzyć rzeczywistość pedagogiczną3.

Interesuje mnie to, jak wiedza pedagogiczna może być tworzona w toku praktyki pedagogicznej i dla niej samej. Celowo zatem nie używam takich określeń, jak nabywanie czy zdobywanie wiedzy, a nawet jej odkrywanie czy uzasadnianie. Wiedza dana, która przybiera postać wiedzy „wyrozumowanej”, jest taka, jak świat ludzki jest dany człowiekowi - oswojona, czyli zarazem arbitralna ${ }^{4}$. Zazwyczaj jest to wiedza zajmująca się uzasadnieniem rzeczywistości pedagogicznej, tej realnej, ale i tej postulowanej. Jest oparta na procedurach rozumu, a ściślej umyśle vel intelekcie, czyli świadomej części ludzkiej psychiki, która generuje postawę przystosowania. Wciąż rozum, który za Aliną Motycką określimy jako pewną zdolność i zarazem pewna postawę jest znanym w kulturze Zachodu instrumentem zapewniającym wiarygodność i sensowność rzeczywistości, w której się partycypuje. Dlatego wiedza jest zazwyczaj kojarzona z dziełem ludzkiego rozumu jako specyficznej ludzkiej zdolności. W zakres takiej zdolności - pisze Motycka - wchodzi umiejętność myślenia pojęciowego (abstrahowania, tj. uzyskiwania pojęć), sądzenia (tj. otrzymywania sądów), myślenia ukierunkowanego (tj. umiejętności prowadzenia dyskursu), rozumowania argumentującego, wyjaśniajacego, uzasadniajacego; dowodzenia (czyli myślenia demonstratywnego); jest to również umiejętność odbierania i poddawania obróbce materiału dostarczanego przez zmysty ${ }^{5}$. Zatem tworzenie wiedzy nie jest aktem dowolnym, bo jej twórca nie jest wolny od siebie samego. Jest zniewolony przez własny proces tworzenia wiedzy, z jednej strony przez rozum i jego prawidła i procedury, które kierują tym procesem i które zależą od ludzkiej woli ${ }^{6}$. Z drugiej

2 Ten aspekt wiedzy pedagogicznej odnosi się zarówno do wiedzy tworzonej przez - wciąż dychotomicznie przedstawianych - tzw. pedagogów-praktyków, jak i przez pedagogów-teoretyków, a to dlatego, że w obu przypadkach można potraktować ją w kategorii wytwarzanego tekstu, który "coś” i „komuś” „coś” komunikuje. To znaczy, że wiedza pedagogiczna wytwarzana jest w medium komunikacji i komunikację podtrzymuje, zmienia, kreuje itp.

3 Por. T. Kuhn, Dwa bieguny, PIW, Warszawa 1985. W tym miejscu wypada wskazać, że oprócz związków i podobieństw między wiedzą o rzeczywistości pedagogicznej a nią samą istnieją różnice, które mogą wywoływać napięcia między nimi. To zagadnienie nie jest jednak przedmiotem niniejszego artykułu.

4 A. Motycka, Rozum i intuicja w nauce. Zbiór rozpraw i szkiców filozoficznych, Eneteia, Warszawa 2005, s. 102.

5 Ibidem, s. 102.

6 Por. Giorgio Colli w swej filozofii ekspresji o rozumie jako odpowiedzi na niesamodzielność ludzkiej ekspresji pisze tak: Rozum narodził się jako pewne uzupetnienie, którego usprawiedliwieniem jest coś ukrytego, coś na zewnątrz niego, co nie może być odzyskane, lecz jedynie wskazane przez 'dyskurs'. Następnie przychodzi złudzenie, że rozum jest sam w sobie swoim celem. Pojawia się nowa perspektywa i nowe sformułowanie, trwa postuszeństwo wobec struktury i regut logosu, który jednak pierwotnie był tylko pewnym narzędziem pomocniczym. Tenże, za: H. Buczyńska-Garewicz, Prawda i złudzenie. Eseje o myśleniu, Universitas, Kraków 2008, s. 297. 
jednak strony przez nieświadomość 7 . Oba te czynniki, czyli ani rozum jako dyspozycja świadomej części ludzkiej psyche, ani nieświadomość, zespolona ze świadomością, nie są pustymi naczyniami wypełniającymi się stopniowo $\mathrm{w}$ toku doświadczenia indywidualnego. Zarówno rozum - idąc śladami Kanta - zawiera pewne aprioryczne kategorie, jak i psyche, której nie da się sprowadzić tylko do owego rozumu. Korelatem apriorycznych kategorii rozumu są w psyche nieświadome dyspozycje, które każdy człowiek dziedziczy, a nie zdobywa na drodze własnego doświadczenia ${ }^{8}$.

Spośród koncepcji nieświadomości - obecnych w filozofii i psychologii ${ }^{9}$ odwołuję się w niniejszym artykule do tej, która jest autorstwa Carla Gustawa Junga $^{10}$. Jest ona związana $\mathrm{z}$ takimi osiowymi subkomponentami jego teorii, jak z koncepcją nieświadomości zbiorowej ${ }^{11}$, archetypów, typów psychologicznych $\mathrm{i}$ ich funkcji, rozwoju osobowości z koronnym dla niego procesem indywiduacji oraz koncepcją jedności przeciwieństw, jak i z koncepcją synchroniczności. Według Junga - a dalej w psychologicznych koncepcjach postjungowskich, a zatem we wszystkich kierunkach psychologii głębi - nieświadomość wraz ze świadomością są integralnymi siłami dynamizującymi indywidualną psyche. Oznacza to, że nie można utożsamiać psyche ze świadomością. Jung pisze (...) psyche stanowi bezpośrednie doświadczenie naszego życia $i$ istnienia. Jest ona sama dla siebie jedynym i bezpośrednim doświadczeniem, jest conditio sine qua non subiektywnej rzeczywistości

7 Jak podkreślają przedstawiciele polskiej psychologii kultury, implikacje psychologii nieświadomości na obszarze filozofii nauki, wiedzy o kulturze (choć tutaj trzeba byłoby wspomnieć chociaż teorie S. Halla, J. Cambella, E. Neumanna, J. Hillmana), teologii, a także w socjologii, religioznawstwie czy psychologii religii (oprócz badań K.G. Junga, J. Rudina, A. Moreno, E. Drewermanna), psychologii języka (F. Lacan), i dodajmy - także w pedagogice (oprócz np. implantowanej na grunt polski myśli Bernie Neville'a) - to raczej sprawa przyszłości. Z. W. Dudek, A. Pankalla, Psychologia kultury. Doświadczenia graniczne i transkulturowe, Eneteia, Warszawa 2005. Natomiast zdaniem Junga, jak pisze o tym Kazimierz Pajor: ważnym kryterium naukowości jest to, czy dana dziedzina jest w stanie otworzyć się na poznanie całej rzeczywistości. Teza ta ma szczególne znaczenie w psychologii, która "musi uwzględniać to, co irracjonalne" (...). Irracjonalność nie utożsamia się tu z nierealnością i może oznaczać np. specyfikę nieświadomych procesów (...). Tenże, Śladami Junga, Eneteia, Warszawa 2006, s. 181. Uważam, że uwaga ta jest równie stosowna pod adresem pedagogiki.

8 K. Pajor, Psychologia archetypów Junga, Eneteia, Warszawa 2007, s. 158.

9 Patrz: B. Dobroczyński, Ciemna strona psychiki, Księgarnia Akademicka, Kraków 1994; Nieświadomość jako kategoria filozoficzna, pod red. A. Motyckiej, W. Wrzosek, IFIS PAN, Warszawa 2000.

10 Jak pisze K. Pajor: Jungowska koncepcja nieświadomości jest wyjątkowa, daleko wykracza poza model Freuda i obejmuje ogót procesów rozwojowych ludzkiego ducha w ogóle. Tenże, Psychologia archetypów Junga..., s. 21.

${ }^{11} \mathrm{~W}$ psychologii jungowskiej niemożliwe jest mówienie o człowieku, a zapominanie o kulturze. Jak pisze Zenon Waldemar Dudek: Aby badać zwiazki procesów psychicznych z kultura, trzeba przyjąć, że psychika posiada swoiste "receptory" $i$,aktywatory" fenomenów kultury. Są nimi archetypy, wyrażające podstawowe wymiary życia psychicznego, społecznego i duchowego. Tenże, Psychologia integralna Junga, Eneteia, Warszawa 2006, s. 141. Istnienie archetypów nie jest zależne od jednostki, od jej czasowego istnienia, choć z drugiej strony to właśnie jej psyche stanowi warunek ich istnienia w danej rzeczywistości kulturowej. Nieświadomość zbiorowa jest poniekąd rodzajem filogenetycznego skarbca, w którym to wszystko, co człowiek na przestrzeni tysiacleci ciagle ponownie przeżywat, stato się dziedzictwem każdego indywiduum. K. Pajor, Psychologia archetypów Junga..., s. 172. 
świata w ogóle ${ }^{12}$. Ale tym, czego bezpośrednio nie doświadczamy, jest $p s y c h e$ nieświadoma, dlatego nie można jej bezpośrednio poznać. Poznajemy tylko jej przejawy. Psychologiczne procesy nieświadomości dają się badać tylko pośrednio, czyli poprzez skutki, jakie wywołują. Jest ona nie tyle dostępna w świadomości, co poprzez nią się przejawia. Jest to jednak osobliwe przejawianie się, bowiem jak mówi Jung: Niezależnie od tego, co możemy powiedzieć o nieświadomości, i tak zawsze mówimy o świadomości, a to dlatego, że jej język jest językiem akauzalnym, pozaczasowym i alogicznym ${ }^{13}$. A nie jest to język, do którego przywykliśmy, a raczej nie jest to język, który uchodziłby za prawomocny $\mathrm{w}$ zracjonalizowanym świecie, w którym rozum sprowadza się do umysłu z jego znanymi już z psychologii poznawczej funkcjami. Język i myślenie nieświadome są intuicyjne, spontaniczne, instynktowne, niekierowane, czyli charakteryzują się dużą autonomią wobec woli, $\mathrm{w}$ przeciwieństwie do języka i myślenia świadomego, zdominowanego przez zasady logiki umysłu, którymi rządzi właśnie wybór, a ten (...) wymaga kierunku, aby jednak można było wybraćkierunek, należy wykluczyć wszystko, co do niego nie należy. Z tego stanu siła rzeczy wynika jednostronność znamionująca orientację świadomości ${ }^{14}$. Nieświadomość jest jednak równie żywa, jak i świadomość, tym samym nieświadoma percepcja - tak istotna dla tworzenia wiedzy - charakteryzuje się wysoko rozwiniętą intelektualnie aktywnością, której efekt przebiega nie tyle automatycznie, co raczej spontanicznie i autonomicznie w stosunku do świadomości ${ }^{15}$. Różnica między świadomością a nieświadomością nie dotyczy tylko sposobu ich funkcjonowania, lecz także treści i ich tendencji.

Niniejszy tekst nie jest apoteozą myśli Junga, ale nie zajmuję także krytycznego do niej stanowiska. Odwołując się do niej chcę zwrócić uwagę na jeszcze jedną z możliwych perspektyw w odkrywaniu rzeczywistości pedagogicznej, jej rozumieniu i interpretacji oraz określaniu kierunków jej zmiany. W dzisiejszych czasach w dociekaniach nie tylko z zakresu nauk humanistycznych, chcąc nie chcąc, natykamy się na Junga. Tylu, ilu ma zwolenników i kontynuatorów, tylu ma także krytyków. Słowem, obok jego psychologii analitycznej i integralnej nie sposób przejść obojętnie osobie, której zainteresowania - proszę wybaczyć banał - oscylują wokół człowieka i jego osobowości oraz jego powiązań z kulturą.

Kilka uwag wypada jednak w tym miejscu poczynić. W psychologii ówczesnej/współczesnej kontrowersyjna okazuje się jego perspektywa uwzględniająca psyche i nie pomijająca faktu, że człowiek ma duszę, a rozwój tego, co zwykło się określać osobowością, zasadza się na rozwoju ducha. To indywiduacja rozumiana - w dość dużym skrócie - jako proces rozwoju siebie samego poprzez przekraczanie indywidualnego ego w kierunku spełniania siebie jako człowieka, w którym to

\footnotetext{
12 C.G. Jung, Symbole przemiany. Analiza preludium do schizofrenii, Wrota - KR, Warszawa 1998, s. 344 .

C.G. Jung, Podstawy psychologii analitycznej, Wrota - KR, Warszawa 1995, s. 13-14.

14 C.G. Jung, Typy psychologiczne, Wrota - KR, Warszawa 1997, s. 764. Dla świadomości typowe jest myślenie logiczne, abstrakcyjne, czasowe, przyczynowe i zorientowane na świat zewnętrzny.

15 K. Pajor, Psychologia archetypów..., s. 165.
} 
procesie świadomość jest zarówno częścią, jak i swoistym jego warunkiem ${ }^{16}$. Powiązanie tej koncepcji z wizją kultury - dla niektórych badaczy - w wielu miejscach przybiera aspekty redukcjonizmu. Króluje w tej myśli psychologizm ${ }^{17}$. Z jednej strony nie można się dziwić, bowiem jest to „tylko sposób myślenia wychodzacy od psychicznych cech jednostki, interpretujacy zjawiska społeczne jako przejawy lub pochodne psychiki", powiedza przychylnie nastawieni. Psychologizm to jednak czasami podejście "nothing but", nic poza psychikg - odpowiedza oburzeni przedstawiciele nauk o kulturze ${ }^{18}$. Odniesienie kultury do człowieka i człowieka do kultury nie zatrzymuje się w koncepcji Junga na powierzchni zjawisk. Koncepcja archetypów nieświadomości zbiorowej to wejście w najgłębsze obszary kultury, a tym samym wejście do „wewnątrz” człowieka, ponieważ opierała się ona na analizie zjawisk i treści kulturowych „odbijających się" w jego psychice. Dla Junga odsłaniają one zarówno ciemną stronę ludzkiej natury, jak i stanowią twórcze tendencje ku integracji psyche. Człowiek pozostał tworem kultury, ale nie tylko determinowanym przez jej społeczne aspekty i własną świadomość, lecz także przez nieuświadamiane znaczenia. W tym miejscu można mówić o esencjalizmie jego teorii, podkreślając tym samym jej irracjonalizm i idealizm. I tak koncepcja archetypów nieświadomości zbiorowej miałaby być koncepcją pewnych stałych, niezmiennych i obecnych pod powierzchnią rzeczywistości istotności, które - wszak tak są określane - pełnią rolę wzorców w rozwoju indywidualnym i kulturowym. Myślenie Junga idzie jednak nie w kierunku kauzalnym, jak u Freuda, lecz teleologicznym - jest zorientowane na przyszłość i finalizację. Jung bowiem wyraźnie opowiadał się, że jego wręcz misją jest doprowadzenie tego, co nieświadome, do świadomości, do wskazania na nie tylko możliwe, ale i konieczne w rozwoju indywidualnym (wiodącym ku indywiduacji) i kulturowym konfrontację i dialog między nimi.

Teoria Junga jest nasycona psychobiograficznym elementem - dla niektórych może wydawać się wręcz "pamiętnikarską”, pozbawioną zatem obiektywizmu19.

16 Świadomość może także ten proces blokować. Przy czym dla Junga nie sama świadomość odgrywa kluczową rolę w całości procesu indywiduacji, ale jej stosunek do nieświadomości. To bardzo ważne założenie dla poruszanej w niniejszym artykule problematyki.

17 Sam Jung odżegnywał się od psychologizowania jaźni, tym bardziej, że ona sama nie ma charakteru subiektywnego - jest pewną całością, z której indywidualność i tożsamość dopiero się wyłania. Nie jest też ukoronowaniem rozwoju duchowego, lecz warunkiem wszystkich jego wyższych form.

18 A. Pankalla, O spotkaniu kwadratu z kulą. Jung po polsku, [w:] Fenomen Junga. Dzieło. Inspiracje. Wspótczesność, pod. red. K. Maurina, A. Motyckiej, Eneteia, Warszawa 2002, s. 219.

19 Por. F. McLynn, Carl Gustaw Jung, Zysk i s-ka, Poznań 2000. O powyższej biografii Junga K. Pajor wypowiada się następująco: Wiele książek poświęconych Jungowi stanowi solidna prezentację jego osoby oraz psychologii, ale nie brak też takich, których autorzy zadowolili się powierzchownościa, produkując lub przyjmując od innych różne błędne poglądy na temat Junga i jego psychologii. Przykładem jest przettumaczona na język polski obszerna biografia Junga, jaka napisat Frank McLynn. Wyczuwa się wprawdzie lekkość jego pióra, ale na tym koniec. (...) Chętnie nazwatbym ją "krytyczną biografią", gdyby zastużyła sobie na to. Być może McLynn miał nawet takie aspiracje, lecz to, czego dokonat, nie ma nic wspólnego z naukowo-krytycznym opracowaniem, od którego wymaga się wnikliwych analiz i zamieszczenia oryginalnych wypowiedzi krytycznie ocenianego autora. McLynn tymczasem, odwołując się do poglądów Junga, często przytacza nie jego wypowiedzi, lecz własne ich in- 
Ten osobliwy styl również doczekał się krytyki, która w konkluzji nawet odmawia miana naukowości jego teorii ${ }^{20}$. Problemem może być także - podkreślany w polemice i krytyce jego myśli - mityczny, a dla niektórych także metafizyczny, charakter koncepcji kultury i osobowości oraz ich symbiozy. Jung, łącząc wiele dziedzin w jedną całość, analizował bowiem zjawiska, których powszechnie nie uznaje się za warte naukowego zachodu. Do nich zazwyczaj zalicza się obecną w jego dziełach alchemię, okultyzm, astrologię, ale także magię czy tzw. zjawiska parapsychologiczne. Studiował filozofię Wschodu, religie dawnej Europy, gnostyczne teksty wczesnego chrześcijaństwa, jak i teksty mitologiczne z kolebki kultury Zachodu. Odbył podróże antropologiczne do Ameryki i Afryki. Jednak jego wkład do współczesnej antropologii i psychologii sprowadza się nieraz do kategorii ezoterycznej gnozy, a jego samego określa się jako nawiedzonego proroka ${ }^{21}$. On sam uważał się jednak za empiryka, choći ów empiryzm jest również poddawany krytyce za brak respektowania kategorii naukowości ${ }^{22}$. Pisał: Jest rzecza osobliww, iż moi krytycy, z nielicznymi wyjątkami, przemilczają to, że jako lekarz wychodzę od faktów empirycznych, których sprawdzenie przysługuje każdemu. Za to jednak krytykują mnie, jakbym byt filozofem czy gnostykiem, który udaje, że dysponuje poznaniem nadzmysłowym. Naturalnie, tatwo jest atakować mnie jako filozofa czy spekulującego heretyka. Z tej racji woli się przemilczać odkryte przeze mnie fakty23.

Warto w tym miejscu wspomnieć o języku teorii Junga, który rzutuje również na jej percepcję. Jest to język często nie tylko aluzyjny, ale i wieloznaczny (czy też wielowartościowy), co dla niektórych łączy się z brakiem precyzji wypowiedzi. Tak na przykład niektóre określenia jaźni uznaje się za wzajemnie się wykluczające. Jaźń, będąca dla Junga centralnym archetypem porządku psyche i ukierunkowania na ów porządek, jest także określana - na co wskazuje Zofia Rosińska powołując się na wyróżnienie J. Redfearna - jako:

- jedność kosmiczna, rozumiana analogicznie do wschodnich koncepcji, gdzie oznacza jedność ze wszystkimi zjawiskami żywymi i nieożywionymi;

- catość indywiduum;

- doświadczenia całości;

- sity pierwotne, elementy organizujące, inne niż świadome "ja";

- organizujacce centrum nieświadomości;

terpretacje. W ten sposób krytykuje Junga, którego sam wykreowat. K. Pajor, Śladami Junga, Eneteia, Warszawa 2006, s. 9-10. Krytyczną recenzję kolejnej książki o teorii Junga autorstwa Richarda Nolla pt. The Jung Cult. Originis of a Charasmatic Movement napisał Mirosław Piróg. Tenże, Jung okiem krytyka, [w:] Fenomen Junga. Dzieto. Inspiracje. Wspótczesność..., s. 35-43.

${ }^{20}$ Trywialność i nienaukowość oraz śladowy wpływ na filozofię i nauki humanistyczne często zarzucano także Freudowi. Zwłaszcza wówczas, gdy kontakt z jego psychologią był pobieżny i nasycony uprzedzeniami. Por. P. Dybel, Okruchy psychoanalizy. Między teoria Freuda i poststrukturalizmem, Universitas, Kraków 2009.

${ }^{21}$ Por. np. artykuły z czasopism „Czwarty Wymiar", „Nie z tej Ziemi”.

22 Nie wdaję się tutaj w dyskusję na temat ujmowania samej „naukowości” w nauce. Czytelnika odwołuję do stosownej literatury na ten temat z zakresu współczesnej filozofii nauki.

23 C.G. Jung, za: G. Wehr, Carl Gustaw Jung, Wydawnictwo Dolnośląskie, Wrocław 1998, s. 183. 


\section{- ujawniające się fragmenty nieświadomej jaźni $i^{24}$.}

Nie ulega jednak wątpliwości, iż Jung trwale zapisał się w tych nurtach psychologicznych i psychoterapeutycznych, które ukierunkowane są na potencjał człowieka, jego aktywność twórczą, jego wymiar duchowy. Jego wybrane koncepcje, jak np. koncepcja typów psychicznych, archetypów i nieświadomości zbiorowej, wprowadzają nowe perspektywy w analizach kultury i pozwalają (a może nawet zmuszają) na reinterpretację procesów kulturotwórczych ${ }^{25}$. Podobnie jak psychoanaliza Freuda, tak i psychologia analityczna i integralna Junga nie jest tylko teorią psychologiczną, ale wywarła ona również ogromny wpływ na dwudziestowieczną humanistykę. Obie, wprowadzając nowy dyskurs o człowieku i kulturze, inspirują go w dalszym ciągu - również poprzez ich krytykę.

\section{Nieświadomość i wiedza potoczna jako archeologia wiedzy pedagogicznej}

Uwzględniając jedność świadomości i nieświadomości $\mathrm{w}$ indywidualnym rozwoju psyche, wskazuję - za Aliną Motycką - na znaczącą rolę idei w tworzeniu wiedzy. Będzie to oznaczało, że tworzenie wiedzy zapośredniczone jest $\mathrm{w}$ idei jako tym, co nie jest bezpośrednio odczuwane, widzialne i poznawalne, ale nie jest zupełnie dowolne ${ }^{26}$. Idea jest nieostra i niewyrazista, ale zarazem to ona jest uprzednia w stosunku do tworzenia wiedzy o świecie, jak i w samej wiedzy tkwi w sposób decydujący o jej strukturalizacji i funkcji oraz jej granicach ${ }^{27}$. To ona również decyduje o wyborze dostępnych człowiekowi sposobów widzenia i rozumienia świata. Idea jako taka - odwołując się do psychologii archetypów Junga, o której nieco szerzej w dalszej części artykułu - obok obrazów i symboli jest wy-

24 Z. Rosińska, Jaźń i poczucie sensu, [w:] Fenomen Junga. Dzieło. Inspiracje. Wspótczesność..., s. 101.

25 W tym miejscu warto dodać, iż Jung jest także przedstawiany jako uczeń Z. Feuda i jeden z dysydentów ruchu psychoanalitycznego. W konsekwencji rodzić to może opozycyjność: albo opowiedzenie się za Jungiem, albo za Freudem. Tymczasem można wskazać linie kontynuacji czy komplementarności. Z.W. Dudek pisze: idac w swoich rozważaniach w kierunku badania mitów, symboli, religii $i$ kultury, Jung raczej dopowiadał do stwierdzeń psychoanalizy swoje "rozszerzające” koncepcje (aktywna wyobraźnia i metoda amplifikacji obok metody swobodnych skojarzeń, nieświadomość zbiorowa obok nieświadomości indywidualnej, freudowskiej, archetypy obok kompleksów itp.). Ale z drugiej strony można powiedzieć, że to dzięki Jungowi i jego krytyce freudowskiej psychoanalizy, a w dalszej kolejności jego studiom kulturowym, Freud podjął w swojej twórczości tematy z pogranicza psychologii i kultury, publikując np. Totem i tabu, Kultura jako źródło cierpień. Z.W. Dudek, Freudowska i Jungowska psychologia kultury - konflikt i dialog, [w:] Fenomen Junga. Dzieło. Inspiracje. Wspótczesność..., s. 200.

26 A. Motycka, Rozum i intuicja w nauce..., s. 111-124, 156-157; A. Motycka, Człowiek wewnętrzny a epistéme. Zbiór rozpraw i szkiców filozoficznych o nauce, Eneteia, Warszawa 2010, s. 34-41.

27 Por. Analizując filozofię ekspresji Giordzio Colli, Hanna Buczyńska-Garewicz w eseju pod znamiennym tytułem Kto mówi, pisze: W tym, co obecne, widoczne i dotykalne tkwi bowiem zarazem aluzja do niewidocznego, nieobecnego, niedotykalnego. (...) Świat jako przedstawienie, lśniacy i połyskujący po wierzchu, kryje w sobie rzeczywistość nieznaną i nieuchwytna, a zarazem warunkująca wszelkie zewnętrzne pojawienia się (...). Taż, Prawda i złudzenie..., s. 285-291. 
obrażeniem archetypowym, które na przestrzeni dziejów, jak również w życiu indywidualnym, może obrać różne formy zracjonalizowania swej treści ${ }^{28}$. Treści archetypowe, leża u podstaw wszelkich aktów myślowych, wszystkich naszych poglądów - nawet naukowych - i które w znacznym stopniu na nie wptywają29. Są zatem elementami nieświadomości zbiorowej, które „przebijają się” do indywidualnej nieświadomości. Uwzględniając $w$ procesie tworzenia wiedzy wagę czynnika osobowościowego, powiązanego nie tylko ze sferą racjonalną, ale także i z nieracjonalną, to właśnie idea archetypowa jako aktywny archetyp ukierunkowuje tworzenie wiedzy i na nią oddziałuje. To ona nadaje porządek i formę materiałowi świadomości, a zatem przejawom racjonalności ${ }^{30}$.

W tworzeniu wiedzy pedagogicznej intrygujące jest dla mnie nie tyle, skąd tworzący wiedzę pedagogiczną czerpie materiał na nią - z jakiej idei ujętej tutaj jako wyobrażenie - ile to, jak do idei dociera, a raczej, z jakiego obszaru jego osobowości „przemawia” do niego jaka idea.

Podstawowym źródłem wiedzy człowieka o otaczającym świecie jest - jak pisze Krystyna Ablewicz: jego potoczne bycie w świecie, czy raczej potoczne tegoż świata rozumienie ${ }^{31}$. Potoczne bycie w świecie można określić mianem wiedzy w szerszym rozumieniu - tak, jak rozumie to na przykład Janusz Gnitecki. Wówczas wiedzą określilibyśmy: (...) wszelki zbiór informacji, pogląów i wierzeń, którym przypisuje się wartość poznawcza i/lub praktyczną. W tym ujęciu wiedza może odnosić się do wielu różnych typów racjonalności oraz wykraczać poza wiedzę naukowąa ${ }^{32}$. Na potoczne rozumienie świata nakłada się wiedza $\mathrm{w}$ węższym rozumieniu, tzn. wiedza naukowa (różnie rozumiana w obrębie poszczególnych nauk, jaki w filozofii nauki). Ta wydaje się być kreacją ludzkiego umysłu, który zwykło utożsamiać się z rozumem, o czym pisałam powyżej. Tyle że w procesie tworzenia i tego typu wiedzy nie można już wyrugować czynników, które stanowią o całości człowieka. Wszak jego myślenie nie daje się sprowadzić do myślenia tylko logicznego - ono jest co naj-

28 Patrz: C.G. Jung, Archetypy i symbole. Pisma wybrane, Czytelnik, Warszawa 1976; Tenże, O naturze kobiety, Wydawnictwo Brama - Książnica Włóczęgów i Uczonych, Poznań 1992; Tenże, Podstawy psychologii analitycznej, Wrota - KR, Warszawa 1995; Tenże, Symbole przemiany...; Tenże, Typy psychologiczne...; K. Pajor, Psychologia archetypów Junga...; M. Piróg, Indywidualność i archetypy, „ALBO albo. Problemy Psychologii i Kultury" 2001, nr 3, Archetypy.

29 C.G. Jung, Symbol przemiany w mszy, Wydawnictwo Sen, Warszawa 1992, s. 115.

30 A. Walczak, (Samo)świadomość vel (samo)wiedza Ja-aksjologicznego pedagoga, [w:] Taż, Spotkanie $z$ wychowankiem...

31 K. Ablewicz, Teoretyczne i metodologiczne podstawy pedagogiki antropologicznej. Studium sytuacji wychowawczej, Wydawnictwo Uniwersytetu Jagiellońskiego, Kraków 2003, s. 37. Potoczne bycie w świecie to dla mnie heideggerowskie bycie faktyczne, jak ujął to z kolei Marcin Potępa. Tenże, Fenomen faktycznego życia. Martin Heidegger, Genessis, Warszawa 2004.

32 J. Gnitecki, Wstęp do ogólnej metodologii badań w naukach pedagogicznych, t. II, Wydawnictwo Naukowe UAM, Poznań 2006, s. 17. Por. Gdy zaczynamy analizować wiedzę potoczna, wychodzi na jaw to, że jej część stanowi wiedza pochodna, a część - wiedza pierwotna. Co oznacza, że w niektóre sktadniki wiedzy wierzymy tylko z uwagi na coś innego, z czego zostaty wywiedzione, a w inne składniki wierzymy ze względu na nie same, nie opierając się na żadnych zewnętrznych świadectwach. B. Russell, Nasza wiedza o świecie zewnętrznym, Aletheia, Warszawa 2000, s. 75-78. 
wyżej efektem myślenia z różnych typów racjonalności, jeśli zasadne jest w tym miejscu nadal używać określenia „racjonalność”. Zakładam, że tworzenie wiedzy pedagogicznej nadbudowuje się na wiedzę potoczną, związaną z faktycznym $\dot{z} y-$ ciem, zawiera ją w sobie, pomimo że często wobec niej zachowuje się zracjonalizowany dystans. Jest ona wiedzą „przemawiającą" z nieświadomości indywidualnej psyche, stąd mającą znaczenie i w procesie tworzenia wiedzy pedagogicznej w węższym znaczeniu.

Konkludując, wiedza pedagogiczna - nie ta książkowa, lecz żywa, „,działająca w praktyce" - nie jest tworzona dowolnie i poza wszelkimi zasadami teorii poznania i metodologii, najczęściej zapoznanych w trakcie kształcenia uniwersyteckiego. Ale też do nich się nie sprowadza. Ważny jest bowiem czynnik osobowościowy. W tworzeniu wiedzy pedagogicznej nadal kluczowym elementem jest aspekt poznawczy, jednak znaczenie $\mathrm{w}$ tym procesie czynnika osobowościowego, który staje się w niniejszym artykule kluczowym zagadnieniem, wynika także z przyjęcia założenia o zniesieniu relacji podmiotowo-przedmiotowej, wyrażającej się $\mathrm{w}$ podziale obszaru poznawczego na podmiot poznający i przedmiot poznawany ${ }^{33}$. Upodmiotowienie przedmiotu poznania to jego konstruowanie $\mathrm{w}$ procesie jego poznawalności (i dodajmy: rozumienia) przez podmiot poznający, bez którego sam przedmiot nie daje się pomyśleć poza relacją podmiotprzedmiot. Będąc pedagogiem, egzystuje się w świecie pedagogicznym (czy będzie to klasycznie określany dychotomiczny świat teorii czy praktyki - nie ma tutaj większego znaczenia) - jest się wewnątrz niego. Inaczej mówiąc - nie można, będąc elementem tworzonej wiedzy pedagogicznej, usytuować się na zewnątrz siebie samego. Tym samym wiedza, będąc tworzona przez człowieka, nabywa jego cech - jest konstruowana w złożonych relacjach kulturowych, bo to jest główne miejsce jego przebywania i określania się, czyli jest konstruowana między innymi przez pryzmat płci i role z nim związane, klasy, rasy, języka i innych kontekstów społecznych. Tworzenie wiedzy pedagogicznej jest także tworzeniem „wiedzy dla nas" - tworzących tę wiedzę. Poprzez nią nadaje się własnemu doświadczeniu znaczenia, które w swej istocie są formą przedstawienia sobie tego, JAK się JEST tym, KIM się jest. W tym znaczeniu wiedza pedagogiczna ma swoją strukturę, choć sama w sobie może być także niespójnością przedstawień. Tworzona wiedza pedagogiczna jest zatem pewnym uzupełnieniem rzeczywistości działań pedagogicznych - jest ich źródłem, ale i zarazem rodzi się wraz z nimi. Dlatego została wcześniej określona jako narzędzie pomocnicze w byciu pedagogiem - wszak jest to zawsze wiedza czyjaś i dla kogoś. Jej użyteczność polega na podstawowej funkcji celowości jej tworzenia - bycie obecnym w rzeczywistości pedagogicznej wymaga od uczestnika uchwycenia sensu "przedstawienia” tej rzeczywistości. Nie jest wartością samodzielną, jej wartościowość ujawnia się ze

33 Por. z podejściem jakościowym w metodologii badań, np. Metody badań jakościowych, red. N.K. Denzin, Y.S. Lincoln, t. I, PWN, Warszawa 2009; D. Kubinowski, Jakościowe badania pedagogiczne. FilozofiaMetodyka - Ewaluacja, Wydawnictwo Uniwersytetu Marii Curie-Skłodowskiej, Lublin 2010. 
względu na potrzebę usensowniania własnych działań, nawet jeśli w efekcie skonstatuje się ich bezsensowność. Także wiedza nabyta i oswojona oraz stosowana w praktyce przez pedagoga ma swój sens dopiero za pośrednictwem jego osobowości.

Irracjonalność/nieświadomość jest strukturalnym elementem tworzenia wiedzy pedagogicznej również wówczas, gdy wiedzę tę zapoznaje się i przyjmuje $\mathrm{z}$ arsenału dostępnych teorii pedagogicznych. A zatem pojawia się pytanie o jakość irracjonalności w procesie tworzenia się wiedzy pedagogicznej. I tutaj widzę możliwość połączenia interesującej mnie kwestii z zagadnieniami z zakresu psychologii archetypów Junga, jak i psychologii postjungowskiej ${ }^{34}$. To, że jestem pedagogiem, bo rozważam siebie samego i to, co robię, jeszcze nie mówi mi o tym, „jakim” pedagogiem jestem. Mogę myśleć o sobie, ale to jeszcze nie oznacza, że myślę z głębi siebie samego. Albo mogę myśleć o sobie, ale głębia mnie samego i tak rzutuje na to myślenie. Motywy ruchu myśli mogą być różne, a i sam ruch myśli także. Tym samym chcę wskazać na możliwą zależność między archetypowym wymiarem męskości i kobiecości w rozwoju indywidualnej psyche a rodzajem, strukturą i funkcją posiadanej i tworzonej wiedzy pedagogicznej ${ }^{35}$.

\section{Anima i Animus jako archetypowe wymiary żeńskości i męskości - aspekt pozytywny}

Jungowska koncepcja archetypów zakłada istnienie struktury w sferze nieświadomości zbiorowej odpowiadającej za występowanie określonego materiału wyobrażeniowego ${ }^{36}$. Tą strukturą są właśnie archetypy, które zwykło określać się jako uniwersalne dominanty nieświadomości zbiorowej, które przebijają przez świadomość jednostki nawet wbrew jej własnej i ukształtowanej przez tradycję woli37. Między strukturami nieświadomości zbiorowej a ludzkim doświadczeniem w ogóle istnieje wzajemne uwarunkowanie, tzn. z jednej strony czynione $i$ wielokrotnie powtarzane do-

${ }^{34}$ Dlaczego psychologia Junga i postjungowska? Odpowiedź odnajduję w słowach Z.W. Dudka: Koncepcje Junga (...) należą do pionierskich, dotyczy to zwłaszcza teorii mówiącej o dziedzicznych, archetypowych wymiarach kobiecości i męskości (archetyp Animy u mężczyzn i Animusa u kobiet). Wyprzedzity one psychologię akademicka niemal o pót wieku globalnościa ujęcia kobiecości i męskości jako wymiarów osobowości, świadomości, nieświadomości oraz postaw społecznych i tożsamości kulturowej. Tenże, Płeć psychologiczna, wzorzec kultury i duchowość, „ALBO albo. Problemy Psychologii i Kultury” 2007, nr 2; Cywilizacja i pteć, s. 63.

${ }^{35}$ K. Pajor o jungowskim poglądzie na temat poznania tak pisze: (...) substancjalność myślenia czy poznania nie jest zwiqzana z faktami fizycznymi, lecz stanowi kwestię psychologiczna, to znaczy, że jest uwarunkowana temperamentem. Tenże, Psychologia archetypów..., s. 161. [Podkreślenie - A.W.].

${ }^{36}$ K. Pajor, Śladami Junga..., s. 186.

37 Z.W. Dudek, Archetypowe wzorce w rozwoju indywidualnej psyche, „ALBO albo. Problemy Psychologii i Kultury" 2005, nr 4: Inteligencja archetypów. Typy, stereotypy, symbole, s. 25. Jung pisze: Archetyp aby odwołać się do języka filozofii Kanta - byłby więc czymś w rodzaju noumenu obrazu, który intuicja postrzega i tworzy w akcie postrzegania. Tenże, Typy psychologiczne..., s. 446. 
świadczenia stanowiq źródło i początek praobrazów, z drugiej natomiast archetypy, jako formułowane przez doświadczenie praformy ludzkich przeżyć i doświadczeń, musza mieć fundamentalny wpływ na doświadczenie człowieka ${ }^{38}$. Archetypy są psychodynamicznymi siłami nieświadomości, które, przebijając się przez świadomość, organizują i usensowniają oraz normalizują doświadczenia na poziomie świadomości indywidualnej oraz w wymiarze społecznym i kulturowym ${ }^{39}$. Do podstawowych archetypów, obserwowanych w różnych kulturach, epokach i w rozwoju indywidualnej psyche, Jung zaliczył: Cień, Animusa, Animę, Wielką Matkę, Starego Mędrca i Jaźń. Przyjmując jungowskie założenie, że każdy człowiek jest niejako dwupłciowy, to znaczy jego psyche posiada zarówno męskość, jak i kobiecość, w niniejszym artykule skoncentrujemy się na charakterystyce archetypów Animy i Animusa jako tych, które - obok płci biologicznej i psychologicznej - wyznaczają tak zwaną płeć archetypową (kulturową) ${ }^{40}$.

Animę i Animusa traktuje się jako podstawową parę przeciwieństw w rozwoju indywidualnej psyche, będącą personifikacją męskiej i żeńskiej nieświadomości ${ }^{41}$. W charakterystyce tej szczególne miejsce poświęcę ukazaniu niedojrzałych form asymilacji Animy - pierwiastka żeńskiego u mężczyzny i Animusa - pierwiastka męskiego u kobiety, przyjmując założenie, że mają one wpływ na tworzenie wiedzy pedagogicznej.

Archetypowe cechy nieświadomości pod postacią Animy i Animusa, oprócz cech nabytych w rozwoju indywidualnym przez świadomość (czynniki biologiczne, żeńskie i męskie role i kanony kulturowe, żeńska i męska orientacja świadomości) określają płeć psychologiczną i wypadkową tożsamość ${ }^{42}$. Płeć archetypowa, na ogół nieuświadamiana, ma znak przeciwny niż płeć świadomości biologiczna i psychologiczna. Z drugiej strony to ona dopełnia jednostronny kie-

38 K. Pajor, Psychologia archetypów Junga..., s. 156.

39 Jung przyrównał archetypy do niewidocznych reżyserów, którzy zza kulis dyrygują przedstawieniem. W kulturze objawiają się pod postacią symboli. Patrz np. A. Walczak, O symbolu w kulturze i jego rozumieniu, „Kultura i Wychowanie” 2011, nr 1, s. 87-101.

40 Z.W. Dudek pisze: To, co jest określane obecnie jako rodzaj społeczno-kulturowy związany z ptcią [gender (...)] można rozumieć jako płeć kulturowa - męską lub kobieca, uwarunkowana wrodzona, archetypowa strukturę psychiki, która w naturalny sposób wyraża się również w kulturze. Tenże, Płeć psychologiczna..., s. 63. W jungowskiej i postjungowskiej psychologii płci wychodzi się poza seksualne (poza erotyczne) jej aspekty. Jest to myślenie o płci wolne od panseksualizmu.

41 Jungowska psychologia określana jest mianem psychologii integralnej, opierającej się na przyjęciu hipotezy o jedności świata, w którym wszystko powiązane jest ze wszystkim innym. Także psychika człowieka funkcjonuje na zasadzie przeciwieństw, które mogą pozostawać w dynamicznej równowadze, znosić się lub wzajemne kompensować. Jung wyróżnił następujące pary przeciwieństw: świadomość-nieświadomość, ekstrawersja-introwersja, uczucie-myślenie, intuicja-percepcja, duch-materia. Przeciwieństwa nie są zatem stanem zupełnego wykluczenia, chodzi tutaj raczej-jak pisze K. Pajor - o odmienne tendencje psychologiczne czy sposoby funkcjonowania psyche w różnych sferach. Tenże, Psychologia archetypów Junga..., s. 188.

42 Patrz: cztery współczesne wzorce męskości wg R. Moore i D. Gillete: król, wojownik, kochanek, mag oraz cztery współczesne wzorce kobiecości za T. Wolff (współpracownica Junga), które „unowocześniła" Pia Skogemann: matka, hetera, amazonka, pośredniczka. Z.W. Dudek, Podstawy psychologii Junga..., s. 268-271. 
runek świadomej orientacji płciowej (żeńskie lub męskie ego). Płeć archetypowa ma kolosalny udział $\mathrm{w}$ procesie budowania wewnętrznej osobowości kobiety i mężczyzny oraz rzutuje na ich funkcjonowanie w kulturze, m.in. na ich relacje wynikające z ról społecznych, tendencje matriarchalne i patriarchalne w stosunkach społecznych, w relacjach interpersonalnych ${ }^{43}$. Decyduje także o możliwości skonfrontowania tożsamości płciowej z wartościami, jakie niesie płeć przeciwna. Ma fundamentalny wpływ na doświadczenie człowieka - (...) na konkretne zachowania, nieświadome reakcje i spontaniczne wybory życiowe, których ukryte znaczenie staje się zrozumiałe po dluższym czasie ${ }^{44}$.

Animus i Anima jako archetypy mogą być źródłem rozwoju, udzielając wiedzy i przeżyć archetypowych, albo też mogą stać się przyczyną dezintegracji ego. O dojrzałej tożsamości płciowej decyduje androgynizacja ról płciowych zastąpienie polaryzacji ról płciowych przez kontinuum, w konsekwencji to jednoczenie przeciwieństw staje się składnikiem procesu indywiduacji (tworzenia ducha u Junga). Oznacza to rozumienie płci jako komplementarnego współwystępowania elementu męskiego i żeńskiego - uzupełniającego wymiary indywidualnej $p s y c h{ }^{45}$. Chodzi zatem o wzajemną przynależność nie tylko biegunowych wymiarów (męskości i kobiecości), ale o różnorodność ich przejawów. Nie jest to zatem identyfikowanie się na zasadzie "jednakowości”. Jeśli jednak jest mowa tutaj o "jednakowości”, to w tym rozumieniu, które ujmuje ",jedność" jako siłę wydobywającą i wykraczającą ku czemuś innemu niż to, co jest określone przez pryzmat płci biologicznej, psychologicznej i społeczno-kulturowego wzorca płci - wykraczające właśnie ku czemuś innemu, co jednocześnie jest czymś prymarnym. Akceptacja w sobie pierwiastka przeciwnego i świadomość jego udziału $\mathrm{w}$ dynamicznej relacji przeciwieństw w jedności funkcjonowania indywidualnej psyche pozwala na głębokie przeżycie własnej tożsamości jako kobiety czy mężczyzny oraz wartości, jakie wnosi do tego przeżycia płeć przeciwna ${ }^{46}$. Oznaką rozwoju i dojrzałości świadomości płci jest także świadomość możliwości podejmowania dialogu między przeciwieństwami, umiejętność w pewnych sytuacjach, jeśli to potrzebne, wyboru zachowania charakterystycznego dla danego bieguna ${ }^{47}$. Ta dialogowość ważna jest nie tylko w sytuacjach codziennych, ale

43 Ibidem, s. 255.

44 Ibidem, s. 258.

45 E. Badinter, za: P. Gębala, Schematy i transgresja ptci, „ALBO albo. Problemy Psychologii i Kultury" 2007, nr 2; Cywilizacja i pteć, s. 15.

46 C.G. Jung, Archetypy $i$ symbole..., s. 69-83; Z.W. Dudek, Podstawy psychologii Junga..., s. 260-267; Tenże, Psychologia integralna Junga..., s. 215-227; P. Gębala, Schematy i transgresja ptci..., s. 22-23; K. Kowalski, Z. Krzak, Tezeusz w labiryncie, Ossolineum, Wrocław 1989; P. Skogemann, Kobiecość w rozwoju, Eneteia, Warszawa 2003; O. Vedfelt, Kobiecość w mężczyźnie. Psychologia wspótczesnego mężczyzny, Eneteia, Warszawa 2004.

47 Z.W. Dudek podaje przykład dostosowania odpowiedniego typu postawy i zachowania z zakresu przeciwległego bieguna do sytuacji: (...) nadmierne pobłażanie z pobudek uczuciowych, "litowanie się" nie przynosi efektów, natomiast chłodna logika i zawieszenie uczuć "na kotku” otrzeźwiają niedojrzałą psychikę dziecka i dają do zrozumienia, że chodzi o istotną sprawę. Tenże, Podstawy psychologii Junga..., s. 188. 
szczególnie $\mathrm{w}$ sytuacjach przełomowych, do których można także zaliczyć doświadczenia graniczne. Już samo dostrzeżenie przeciwstawnego bieguna (...) stwarza szansę zwrócenia uwagi "ja" na to, co (...) zawiera - nieznanego, ale autentycznego i cennego ${ }^{48}$. Dobrze zasymilowana Anima u mężczyzny i Animus u kobiety są przewodnikami po labiryncie ich nieświadomości. Umożliwiają nieświadome, symboliczne, intuicyjne i uczuciowe porozumienie z płcią przeciwną, co w konsekwencji przekłada się na psychologiczną niezależność w relacjach kobieta-mężczyzna oraz zdolność do relacji partnerskich. Dopełniają i aktywizują siłę i dojrzałość uczuciową u mężczyzny (zdolność do empatii i umiejętność wyrażania emocji) oraz inspirują do intelektualnej i zadaniowej samodzielności u kobiety (zdecydowanie, zaradność). Są źródłem równowagi psychicznej w sytuacjach skrajnych oraz wzbudzających lęk egzystencjalny. Podsumowując, można zatem wyróżnić następujące cechy charakteryzujące osobę o tożsamości androgynicznej: wysoka integracja wymiaru męskiego i kobiecego, niezależnie od posiadanej płci, zdolność do szybkiej adaptacji w nowych warunkach, integracja wielu opcji aksjonormatywnych, dobra adaptacja społeczna, sprawowanie kontroli nad własnym życiem, niski poziom lęku, pewność siebie, adekwatność eksponowania cech męskich i kobiecych w zależności od sytuacji. Główną zasadę określającą androgynię i jej funkcjonalne znaczenie we współczesnej kulturze Przemysław Gębala określa jako (...) dążenie do tego, by zachowania społeczne pozbawione byly nacechowania płciowego odpowiadającego schematom kulturowym oraz mogły być realizowane niezależnie od uwarunkowań biologicznych ${ }^{49}$.

\section{Polaryzacja archetypu Animy i Animusa}

W procesie asymilacji Animy u mężczyzny i Animusa u kobiety można wyróżnić charakterystyczne aspekty postaw wobec przeciwstawnego bieguna, które mówią o ich polaryzacji ${ }^{50}$. Pierwszą z nich jest biegunowa opozycja (nieświadomość jednego bieguna). Nieświadomy archetyp podlega mechanizmom wypierania. W konsekwencji dochodzi do ignorowania osób o przeciwstawnych cechach, nietolerowanie ich obecności, $\mathrm{w}$ razie kontaktu z nimi pojawia się agresja, nienawiść, odrzucenie, które charakteryzować mogą ogólną tendencję do dominacji. Jest to stan alienacji od archetypu, czyli stan utraconej lub zerwanej z nim więzi. Alienacja wobec Animy charakteryzuje jednostronnie męski typ mężczyzny, negatywnie (obronnie lub agresywnie) ustosunkowany do sfery kobiecej (twardziel, macho, kult męskości, siły i władzy). Mężczyzna często izoluje się od kobiet albo traktuje je instrumentalne. Często z nimi walczy. W życiu zazwyczaj pomija rolę

\footnotetext{
48 Tenże, Psychologia integralna Junga..., s. 158.

49 P. Gębala, Schematy i transgresja ptci..., s. 23.

50 Z.W. Dudek, Psychologia integralna Junga..., s. 156-159, 217-229; Tenże, Podstawy psychologii Junga..., s. 185-189, 267-274; P. Gębala, Schematy i transgresja ptci..., s. 17-21; C.G. Jung, Archetypy i symbole..., s. 69-83; Tenże, O naturze kobiety...
} 
sztuki, piękna, łagodności, poezji, rozrywki, wypoczynku. Alienacja wobec Animusa z kolei charakteryzuje jednostronnie żeński typ kobiety. Główne cechy charakterystyczne to: słabe poczucie indywidualności i niezależności, unikanie zróżnicowania psychicznego i dojrzałych ról kobiecych, uleganie dzieciom w roli matki, słaba, naiwna, bezkrytyczna postawa wobec partnerów, naśladownictwo znanych postaci o powierzchownej osobowości. Niemniej świadomość mężczyzny i kobiety może koncentrować się wokół bieguna przeciwstawnych tendencji do własnej płci biologicznej i psychologicznej. Wówczas w przypadku mężczyzny ta polaryzacja: W skrajnych przypadkach jest czynnikiem zniewieścienia psychiki mę$\dot{z} c z y z n y$, pozostawania w stanie uzależnienia od kobiety (...), co skutkuje pojawieniem się u niego bezładu wewnętrznego, zmiennego usposobienia i sentymentalizmu oraz w niektórych sytuacjach teatralnego zachowania się. Natomiast w przypadku kobiety: Nadmierne zintegrowanie się ego kobiety z archetypem Animusa prowadzi do wykształcenia się męskiego typu kobiety, tzn. dominującej, rywalizującej bezwzględnie $z$ mężczyzna (... $)^{51}$.Taka kobieta charakteryzuje się egotyzmem i emocjonalnym chłodem, w kontaktach z mężczyznami nie brakuje jej uprzedzeń i insynuacji oraz krytyki, którą wysuwa również pod adresem „kobiecych kobiet”, z zachowaniem jednocześnie pewności co do swoich opinii. Wynika to z ekstremalnej niezależności od stereotypowego wizerunku, będącego pochodną cech psychologicznych i ról społecznych, a także wpływów kulturowych słabej choć pięknej płci, co czyni ją często kobietą samotną.

Wyróżnić można także integrację z jednym biegunem, której towarzyszy mała świadomość bieguna przeciwnego. To niedostateczne rozpoznanie bieguna przeciwnego i/lub wyparcie, często zranionej, funkcji psychicznej związanej z danym biegunem. W drugim przypadku balansowaniu między biegunami towarzyszy tłumienie bieguna opozycyjnego. Wypierany ze świadomości przeciwny biegun jest źródłem tzw. kompleksów, lęków, niskiego poczucia własnej wartości, mechanizmów obronnych, unikania zmian, bezradności, niepewności, ogólnego napięcia psychicznego. W konsekwencji może nasilać się działanie mechanizmów obronnych, takich jak racjonalizacja, zaprzeczenie, unikanie.

I trzecia możliwa postawa konstytuuje się na bazie konfliktu przeciwieństw (konfrontacji biegunów). Wówczas nieświadomy obraz Animusa u kobiety i Animy u mężczyzny może kłócić się z wzorem, który świadomie wybierają ${ }^{52}$ Rozdarcie między dwoma, względnie zaktywizowanymi biegunami i balansowanie między przeciwieństwami mogą przetrwać jedynie silne osobowości, opierające

51 Z.W. Dudek, Podstawy psychologii Junga..., s. 269 i 266.

52 Podany przez Z.W. Dudka przykład pozostawania ego w konflikcie między przeciwieństwami można potraktować jako dwubiegunowe zachowanie się kobiety przeżywającej konflikt między obecnym w niej Animusem a swoją częścią żeńskości. Pisze on: Przykładem może być intelektualne, obiektywne zachowanie w pracy, a uczuciowe, emocjonalne wśród przyjaciót $i w$ domu. Do pewnego stopnia jest to rozwiązanie korzystne, jeśli jednak sytuacja domowa wymaga głównie obiektywizmu, a z przyzwyczajenia uaktywnia się postawa uczuciowa, kontrola maleje. I odwrotnie, kiedy w pracy trzeba oprzeć się na postawie uczuciowej, sztywne podejście intelektualne okazuje się nieprzydatne czy wręcz śmieszne. Tenże, Podstawy psychologii Junga..., s. 187. 
się na silnym ego. Konflikt między opozycjami spetnia wówczas funkcje mobilizujące, inspirujące i rozwojowe. Skłania do uświadomienia sobie znaczenia biegunów ${ }^{53}$. W przeciwnym razie osoby $\mathrm{z}$ wybiórczą lub fragmentaryczną asymilacją bieguna przeciwnego nie potrafią funkcjonować w różnych - alternatywnych - środowiskach, ponieważ brakuje im możliwości alternatywnego zachowania, o którym decyduje w dużej mierze świadomy wybór. W konsekwencji ich zachowanie charakteryzuje się uległością wobec rożnych osób i sytuacji lub izolacją od nich.

\section{Poznawcza funkcja Animy i Animusa}

Animus i Anima, podobnie jak pozostałe archetypy, jako żywe centra nie tylko nieświadomości, lecz całej psyche, stanowią zwarty system psychiczny, petniąc w nim wszystkie istotne funkcjes. Obok funkcji integracyjnej i powiązanej z nią funkcji kompensacyjnej - wspólnych wszystkim opisywanym przez Junga archetypom Anima i Animus pełnią funkcję poznawczą i prospektywną (antycypacyjną), czyli warunkują spostrzeganie, poznanie i orientację w świecie. Są one ukierunkowane przede wszystkim na cel doświadczenia, a nie na jego przyczynę, co jest z kolei konsekwencją logicznego funkcjonowania świadomości. Są praformami warunkującymi wszelkie poznanie i jego faktorami, na których zasadza się tworzenie wiedzy - również wiedzy pedagogicznej. Ale jako znaczący element czynnika subiektywnego, poznanie mogą także zdominować. W tym paragrafie skupię się głównie na prezentacji funkcji poznawczej, dokonując zarazem próby charakterystyki wiedzy „wiecznego chłopca” - puer aeternus $\mathrm{i}$ "wiecznej dziewczynki” - puella aeterna, jako przykładów polaryzacji wymiaru męskiego i żeńskiego, kreowanych i podtrzymywanych przez współczesną kulturę Zachodu. W tym miejscu wypada jednak poczynić uwagę, odwołując się do stanowiska K. Pajora: funkcjonowanie archetypów jako żywych organów psyche zachodzi kompleksowo, to znaczy ich oddziatywanie dokonuje się jednocześnie w różny sposób i na różnych płaszczyznach ${ }^{55}$. Dlatego należałoby ich funkcje rozpatrywać w łączności i w odniesieniu do pozostałych archetypów. Nie będzie to jednak przedmiotem niniejszego paragrafu.

Aktywność archetypów w procesie poznawczym wynika z ich własnej inicjatywy i zasadza się na porządkowaniu materiału doświadczenia, które przebiega według określonych wzorców, praobrazów, którymi sa one same, w efekcie czego materiał ten otrzymuje określoną postać56. Jako motywy porządkowania materiału do-

\footnotetext{
53 Ibidem, s. 57.

54 K. Pajor, Psychologia archetypów Junga..., s. 161.

55 Ibidem, s. 155.

56 Ibidem, s. 159. Por. Dan McAdams, dla którego tożsamość opisać można w kategoriach narracyjnych z tej racji, iż począwszy od okresu adolescencji każdy staje się biografem własnego Ja - uważa, że istotnym w narracji człowieka jest jej główny wątek, który przyrównuje się do dominującego motywu w życiu danej osoby. To on wyznacza linię tematyczną, jest on „szkieletem” czy też jej ogólną konstrukcją. Tworzy on linię tematyczną (linie tematyczne), która wraz ze złożonością narracji wiąże w całość następujące jej kategorie: epizody nuklearne, wyobrażenia, tło ideologiczne i skrypty genera-
} 
świadczenia w nich samych dają się także rozpoznać - one w nich przedstawiają samych siebie. Archetypy, jako znaczący czynnik subiektywny w procesie poznania, ujmują sens materiału poznania, jaki człowiek za ich pośrednictwem rozpoznaje i utrwala, choć pierwotnie (i zazwyczaj jedynie tam) dzieje się to w sferze nieświadomości.

Stawiam tezę, iż wiedza o świecie i sobie samym jest poszukiwana i tworzona ze względu na "dopasowanie do potrzeb" wynikających z polaryzacji wzorców męskości i kobiecości (lub z kontinuum - androgyniczności). Spróbuję to pokazać dokonując krótkiej charakterystyki „wiecznego chłopca” (puer aeternus) i „wiecznej dziewczynki" (puella aeterna) w ich aspekcie negatywnym oraz rodzaju, a przede wszystkim celowości tworzenia wiedzy. Zanim jednak przejdę do tego, krótko o kryterium doboru przykładu polaryzacji biegunowych wymiarów żeńskości i męskości. Odwołam się tutaj tylko do znanego stanowiska w psychologii kultury inspirowanej psychologią jungowską, mówiącego o tym, że te formy wyrażania się płci męskiej i kobiecej, określane jako słabo zróżnicowane, u podstaw których jest zatrzymanie się rozwoju pewnych fragmentów osobowości w fazie "prematuralnej", we współczesnej kulturze Zachodu są dość charakterystycznymi wymiarami męskości i kobiecości ${ }^{57}$.

„Wieczny chłopiec" kieruje się tzw. „psychologią pozytywną" - dla niego za pozytywne uchodzi to, co jest łatwe, wygodne i przyjemne. Towarzyszy temu myślenie życzeniowe, które można ująć w formułkę następującej treści: „można sobie coś pomyśleć lub wyobrazić, a to się spełni” lub „wszystko się uda”. Cechuje go również brak precyzji w myśleniu i działaniu, jak również uruchomienie w myśleniu mechanizmów obronnych, dzięki którym zachowuje dobre samopoczucie. W trudnych sytuacjach „wieczny chłopiec” mówi sobie: „można zawsze odłożyć to, co nie jest po mojej myśli lub nie pasuje do moich potrzeb". Zazwyczaj dodaje „na później”, ale nie określa czasu, bo zazwyczaj nie znajdzie dogodnych warunków, aby móc przedsięwziąć to, co nie leży po jego myśli i nie pasuje do jego potrzeb. Problemy z myśleniem hipotetycznym i perspektywicznym, gdzie $\mathrm{w}$ centrum on sam nie zajmuje znaczącego miejsca, przekładają się na przekonanie, że popełniane przez niego błędy, ponieważ nieplanowane („tak wyszło”, „złożyło się") będą naprawione przez inne osoby lub okoliczności. Często też czuje się niezrozumiany, przez co jeszcze bardziej hołubi siebie samego jako twórcę „pozytywnego" myślenia. Jeśli doświadcza niemożności wyartykułowania swoje-

tywne. Dla poruszanych w niniejszym artykule treści ważne wydają się - oprócz dominującego motywu narracji - linie tematyczne. Koncentrują się wokół motywu zażyłości - dążenie do bliskości, ciepła, podtrzymywania związków, oraz motywu siły - dążenie do bycia silnym, wywierania wpływu na otoczenie, ekspansji, podboju. D.P. McAdams, Biography, narrative and lives: An introduction, „Journal of Personality" 1988, no. 56 (1); D.P. McAdams, The Story we Live by - Personal Myths and the Making of the Self, The Gilford Press, New York 1993; U. Tokarska, W poszukiwaniu jedności i celu. Wybrane techniki narracyjne, [w:] Wybrane zagadnienia z psychologii osobowości, pod red. A. Gałdowej, Wydawnictwo Uniwersytetu Jagiellońskiego, Kraków 1999, s. 181-187.

57 Z.W. Dudek, Pteć psychologiczna..., s. 67. 
go stanowiska lub kiedy spotyka się z krytyką, przejawia dużo chłopięcej agresji, żalu i resentymentu. Podsumowując, jego wiedza o nim samym i świecie charakteryzuje się egocentrycznym nadawaniem jej znaczeń. To wiedza, w której może przejrzeć się jako "ja idealny”. To wiedza, którą używa jako „narzędzie” w projektowanych przez siebie kontaktach interpersonalnych. Wówczas dorosły mężczyzna, noszac cechy syndromu wiecznego chłopca, zachowuje cechy duchowości dziecięcej (androgynii), a jednocześnie operuje instrumentalnym myśleniem dorosłego, dzięki czemu potrafi sterować innymi, wywotywać skrajne emocje oraz manipulować grupa ${ }^{58}$. Z drugiej strony jest to także wiedza wiecznie tworząca się, więc w dużym stopniu na każdym jej etapie niedoprecyzowana. Tworząc ją, ",wieczny chłopiec" pozostawia sobie dużą swobodę tzw. "twórczej” interpretacji i przełożenia na praktykę. Jest to także wiedza, w której odnajduje uzasadnienie życzeniowego i pozytywnego (naiwnego) myślenia o tym, w czym partycypuje - od życia osobistego, po życie zawodowe i społeczne. W wiedzy tej nie ma miejsca na precyzję „własnych konsekwencji". Nie bierze odpowiedzialności za jakość swojej wiedzy, ponieważ nie widzi jej jako szkodliwie ingerującej w rzeczywistość, w której on sam partycypuje. Ale z drugiej strony, według niego, konsekwencje jej aplikacji do rzeczywistości leżą po stronie podmiotowych i pozapodmiotowych "czynników zewnętrznych".

„Wieczna dziewczynka” wierzy w swoją cudowność i wyjątkowość. Dlatego znaczenie, jakie nadaje swemu ciału, seksualności, inteligencji, kreatywności, rodzinie i pracy jest podniesione do rangi ideału i misji specjalnej. Opiekę nad dzieckiem i innymi osobami potrzebującymi jej traktuje jako niezwykłe zadanie, przy czym nie widzi jego/ich odrębności i indywidualności („Moje dziecko będzie niezwykłe, to moja wizytówka"). Dlatego zarówno w strefie życia osobistego, rodzinnego, ale także społecznego, w tym życia zawodowego, jej działania opierają się na egocentryzmie. W tworzonej wiedzy o sobie samej i o świecie szuka uzasadnienia swojej pozycji, ale także uzasadnienia swojej wyjątkowości na tle innych („robię to, czego inni nie robią"). Często też szuka takiej wiedzy, której posiadanie i wzbogacanie zapewnia rozwój jej wyjątkowości, z karierą zawodową włącznie. To wiedza, za pośrednictwem której może realizować idealny wizerunek siebie samej i która ten wizerunek potwierdza. To wiedza, która na przykład podkreśla jej pracę jako misję specjalną. Jeśli jest to matka lub kobieta-pedagog, wiedza służy w "oswajaniu” dziecięcego potencjału na kształt przez nią pożądany - poszukuje w wiedzy wskazówek, jak zrobić $\mathrm{z}$ bóstwa dziecięcego Boga.

Płci - z perspektywy psychologii głębi - nie można sobie wybrać dowolnie. Warunkuje nas w dużym stopniu sfera oddziaływania biologiczno-psychologicznego, świadomych wymiarów życia społeczno-kulturowego pod postacią ukrytych i jawnych wzorów, ale także i nieświadomości, która jest powiązania z głębinową warstwą kultury, w której człowiek żył i żyje. Ta z kolei jest żywą materią symboliczną, na którą dopiero nabudowuje się to, co staje się materialnym

58 Ibidem, s. 71. 
i niematerialnym elementem jej samej jako baumanowskiej „fabryki trwałości”59. Wyobrażenia kultury jako fabryki sensu istnienia człowieka, a tym samym fabryki jego trwałości, ulegają zmianie. We współczesnej kulturze Zachodu - obszarze wielu transgresji - przestaje się promować wyraziste i skrajne, najbardziej zróżnicowane pod względem cech płciowych, wzorce kobiece i męskie, jak wyróżnione przez Ole Vedfelta postacie "syn ojca” (męski typ mężczyzny) i „córka matki” (żeński typ kobiety) ${ }^{60}$. Do głosu dochodzą typy pośrednie: „syn matki” (kobiecy typ mężczyzny) i „córka ojca” (męski typ kobiety), o różnym stopniu polaryzacji cech męskich i żeńskich, po spolaryzowanie $\mathrm{w}$ przeciwnym kierunku $\mathrm{w}$ stosunku do płci biologicznej, ale także krótko scharakteryzowane powyżej postacie: „wieczny chłopiec" i „wieczna dziewczynka”. Jak pisze Z.W. Dudek: Z perspektywy psychologii kultury (...) w cywilizacji transformującej się większa pozycję maja jednostki z cechami wiecznego chtopca i wiecznej dziewczynki oraz przedstawiciele mieszanej ptci psychologicznej - syn matki i córka ojca (osoby androgyniczne). Takie osoby uczestniczą bezpośrednio w przemianach kulturowych, w ich psyche rozgrywaja się dramatyczne procesy inicjacyjne dotyczące całej wspólnoty kulturowej, subkultury duchowej, całego pokolenia. (...) Jeślicywilizacja poświęca wiele energii na równouprawnienie ptci, dba o prawa dla jednostek homoseksualnych, to znaczy, że szuka nowych wzorców tożsamości, których ważna częścia jest wymiar męskości i kobiecościbi.

\section{Konkluzja}

Skąd dowiadujemy się o tym, co jest intencjonalnym przedmiotem naszego poznania (intencjonalnym ukierunkowanym przez innych i tym, przez konkretnego człowieka)? Otóż - by odwołać się w tym miejscu do Martina Heideggera nie możemy dowiedzieć się o tym, co jest przedmiotem poznania, czyli zdobyć wiedzy o nim, w oderwaniu od wiedzy o samym tym przedmiocie. $Z$ drugiej strony nie można wiedzieć czegoś i zarazem od tego, czego ta wiedza dotyczy, abstrahować. Powyższe określenia wskazywałyby na mówienie o procesie tworzenia wiedzy w sferze świadomej. W tym miejscu chcę nawiązać do przedstawionego w niniejszym tekście stanowiska psychologii głębi, podkreślającego aktywny udział nieświadomości we wszystkich procesach indywidualnej egzystencji człowieka, ale również w procesach kulturowych. Jednocześnie jeśli czegoś nie wiemy na poziomie świadomości, to nie możemy od tego abstrahować, ponieważ ta operacja mentalna przyporządkowana jest właśnie sferze świadomej. Nie oznacza to jednak, że w tworzonej wiedzy nie przebija czynnik nieświadomego stosunku do tego, co jest jej przedmiotem. Skonstatuję, trawestując pewne założenia filozoficzne M. Heideggera, iż wiedza jest zarówno nieświadomym, jak i świadomym stosunkiem do tego, co jest jej przedmiotem. Pytaniem otwartym pozostaje również

\footnotetext{
59 Z. Bauman, Śmierć i nieśmiertelność. O wielości strategii życia, PWN, Warszawa 1998.

60 O. Vedfelt, Kobiecość w mężczyźnie...

61 Z.W. Dudek, Płeć psychologiczna..., s. 71-72.
} 
i to: „co jest jej przedmiotem?”. W tworzeniu wiedzy króluje zasada odnosząca się do jej pewności, która staje się jej podstawą w ogóle i zaświadcza o jej uzasadnieniu (nawet jeśli ono samo jest tymczasowe). Jak powszechnie przyjmuje się, o pewności wiedzy nie przesądza jednak jej przedmiot, lecz to, czy i jak coś jest pewne, nie $z a s ́ c z y m$ jest to, co jest pewne ${ }^{62}$. Tworzona wiedza jest wówczas pewna dla samego tworzącego, kiedy pokazuje mu rzeczywistość jako taką, która odpowiada rzeczywistości. Ale to tylko jedno ze znanych ujęć pewności wiedzy, polegające na odpowiedniości wiedzy i jej przedmiotu. Dla Heideggera prawdziwa wiedza to taka, która jest wiedzą odkrywającą. I tutaj pojawia się podstawowy warunek odkrycia - aprioryczne zainteresowanie. To, co jest przedmiotem odkrycia, musi być zarazem przedmiotem zainteresowania podmiotu. Ponieważ nie jest możliwe docieranie do rzeczywistości oderwanej od wiedzy, stąd to, jaka jest wiedza podmiotu, rzutuje na docieranie i odkrywanie tego, co jest jej przedmiotem. Aby jednak rzecz ukazała się w wiedzy taką, jaką jest, wiedza powinna być właśnie odkrywającą. Wychodząc z tej heideggerowskiej perspektywy można skonstatować, że archetypowe wymiary męskości i żeńskości - pozostające siłami psyche i pierwotnie bytujące $\mathrm{w}$ sferze nieświadomości - są tym, co skrywa się za tym, co jawne, czyli za ludzką przytomnością. Ważne jest, aby treści archetypów, jako fundamentów psyche, biorących czynny udział w tworzeniu wiedzy, mogły przedostawać się do świadomości i wpływać na ten proces - generować wiedzę do jej dojrzalszych form. Jest to możliwe wówczas, gdy nawiąże się i utrzyma kontakt między rzeczywistym, to znaczy aktualnym doświadczeniem człowieka, a archetypowymi uwarunkowaniami tegoż doświadczenia. W grę wchodzi zatem uruchomienie świadomości siebie samego jako bycia bytem $\mathrm{w}$ byciu faktycznym dokonując $\mathrm{w}$ tym miejscu paraleli do ujęcia bycia i bytu w filozofii Heideggera którego doświadczenie jest uwarunkowane. Dodaję w tym miejscu - uwarunkowane archetypami. Sama świadomość tego nie zaświadcza jeszcze o autentyczności bycia bytem - ona raczej wydarza się niż przynależy do codzienności (co też nie oznacza, że nie zdarza się w codzienności, ale codziennością jednak nie jest). Potrzeba zatem, aby na samą wiedzę, w której ważne jest to, jak coś jest pewne, spojrzeć jako wiedzę tworzoną na bazie odkrywania tego, co jest pewne. To, co jest pewne, to także to, co skrywa się za tym, co jawne - a zatem tym, co jest pewne w tworzeniu wiedzy, są archetypy, które w taki sposób są pewne, w jaki sposób sami jesteśmy nimi apriorycznie zainteresowani, czyli w jaki sposób jesteśmy otwarci na wydarzającą się prawdę swego bycia.

Wiedza pedagogiczna, której nie można sprowadzić do wiedzy metodycznej w tym sensie, że ona sama zaopatruje pedagogów w instrukcje działań, jest wiedzą, którą tworzą oni sami, nawet jeśli jest to wiedza przyjęta przez nich i za ich przyzwoleniem (bardziej nieświadomym niż świadomym) określająca ich działanie. Tworzą ją $w$ tym sensie, że jej sensowność podtrzymują swym

${ }^{62}$ O tworzeniu wiedzy w ujęciu M. Heideggera patrz: K. Michalski, Zrozumieć przemijanie, Kronos, Warszawa 2011, s. 66. Czytelnika odwołuję również do dzieł samego Heideggera i jego ujęcia prawdy alethei. 
działaniem - konserwują ją również poddając ją kontemplacji. Jest to wiedza, którą mają o sobie samych i celowości pedagogicznego działania, jak również o jego instrumentarium. Ale taka wiedza - metodycznie badająca swój własny przedmiot (tzn. również ich samych) - jest zawsze dopełniana sobą samą jako wiedzą będącą zjawiskiem prawdy w sensie pierwotnym ${ }^{63}$. Ta druga strona wiedzy wymyka się ujęciu jej jak gdyby z zewnątrz - jest ona na tyle spleciona z samym człowiekiem i z istotą jego życia, iż nie można obserwować jej z dystansu. Ona żyje własnym życiem i tylko dzięki myśleniu - czy szerzej dzięki przytomności - można w niej uczestniczyć. Ale można też poprzez swe uczestnictwo w wiedzy pierwotnej zasłaniać jej charakter (polaryzacja archetypów). To znaczy, że wiedzę pedagogiczną nie tylko współkonstytuuje pierwiastek osobowościowy pedagoga, ale zarazem jest on źródłowy w stosunku do niej właśnie poprzez żywą sferę nieświadomości przebijającą się do świadomości.

Jeśli nauczyciel/pedagog ma być "transformatywnym intelektualistą", co postuluje pedagogika emancypacyjno-krytyczna, sprzymierzeńcem słabszych grup społecznych oraz bezpośrednim tłumaczem między człowiekiem i złożonym światem społeczno-kulturowym - pomocnikiem w krytycznym rozumieniu tegoż świata, ważne wydaje się być to, jak kształtuje się jego kulturowa tożsamość płciowa, która w świecie tym jest zakotwiczona przez pryzmat ról związanych z kategorią płci. Chcę jednak wyraźnie zaznaczyć, iż „przebijanie się” do nieświadomych pokładów swojej wiedzy pedagogicznej przez pryzmat tylko „zewnętrznej" o niej wiedzy nie może stać się nałożoną na niego powinnością (w sensowność której i tak należałoby wątpić z etycznego punktu widzenia) ${ }^{64}$. Zdejmując "różową perspektywę" z osoby pedagoga i schodząc na "pedagogiczną ziemię" powiem, iż nie każdy ma potrzebę posiadania wiedzy o sobie - takiej, o której pisałam powyżej, to znaczy, która prowadzi na drogę rozwoju osobowości i która tej drogi jest elementem. Przychylam się w tym miejscu do stanowiska Junga, które przytacza K. Pajor: „wyższy stopień uświadomienia” osiagna tylko te osoby, które "maja do tego przeznaczenie i powołanie, to znaczy zdolność i pęd do wyższego zróżnicowania"65.

\footnotetext{
63 Ibidem, s. 114.

64 A. Walczak, W kierunku etyki jako sztuki odstaniania i tworzenia pedagogicznego ethosu, [w:] Taż, Spotkanie z wychowankiem...

65 Jung, za: K. Pajor, Śladami Junga..., s. 114. Biorąc pod uwagę przytomność w dochodzeniu do pełnej wiedzy - wiedzy prawdziwej, widzę paralelę słów Junga z ujęciem myślenia M. Heideggera, o którym K. Michalski pisze tak: (...) myślenie nie jest samo dla siebie, lecz jest za każdym razem „odpowiedzią" na "wołanie" bycia - mówiąc mniej abstrakcyjnie: myślenie jest odpowiedzią na pewna potrzebę, tyle, że nie "ludzkq", lecz potrzebę samej prawdy. Jeszcze inaczej: myślenie ma strukturę celowa, jest z istoty myśleniem ze względu na ujawnianie się bycia. (...) zawiera się w nim moment niezaspokojenia, niejawności-i to jest zaczynem jego dziania się. Tenże, Zrozumieć przemijanie..., s. 115-116. Celem myślenia ma być zatem nie rozwiązanie problemu, lecz jego odkrycie. Zob.: M. Heidegger, Co znaczy myśleć?, [w:] Filozofia wspótczesna, pod red. J. Tischnera, Instytut Teologiczny Księży Misjonarzy, Kraków 1989; A. Walczak, Od myśli do myślenia dialogicznego pedagoga, [w:] Taż, Spotkanie z wychowankiem...
} 
$\mathrm{Na}$ „namacalną” rzeczywistość działania pedagogicznego, dającą się zobaczyć i (z)rozumieć z perspektywy teorii fenomenologiczno-hermeneutyczno-dialektycznych (i/lub racjonalnie wyjaśnić - w ramach dostępnych, znanych, preferowanych itp. teorii pedagogicznych), nakłada się rzeczywistość wiedzy pedagoga, którą warunkuje m.in. jego archetypowa płeć - stopień (poziom?) asymilacji męskich i żeńskich cech w rozwoju indywidualnej psyche. To „nałożenie” jest wszak specyficznego rodzaju, bo raczej warunkuje i określa rozumienie i wyjaśnianie rzeczywistości działania pedagogicznego niż jest jego dodatkowym elementem, jakby nadwyżką, czyli swojego rodzaju elementem dekoracyjnym, bez względu na to, czy pasującym, czy też nie, do całości. Według psychologii jungowskiej i postjungowskiej jest to rzeczywistość „faktyczna”, bo działania symboliczne (a w nich przejawia się nieświadomość) nakładają się na warstwę widocznych działań w relacjach interpersonalnych i intrapersonalnych, które stanowią meritum działań pedagogicznych. Bez pierwszych nie obywa się żadne działanie pedagogiczne, bez drugich - również, przynajmniej jeśli myślimy o „dobrym" pedagogu, to nie powinno się obywać.

Ponieważ archetypowe wzorce rozwoju indywidualnej psyche pedagoga (np. różne formy asymilacji Animy i Animusa) są działaniami "z głębi”, to w faktycznych relacjach ekstra- i intrapersonalnych, będącymi śladami nieświadomości, trudno je odszyfrować. To znaczy, że ich zawoalowana forma przejawiania się (choć obserwowana w konkretnych zachowaniach) nie daje jednoznacznych konkluzji interpretacyjnych. Tym bardziej, że "problemy” z asymilacją Animy i Animusa mogą utwierdzać rytuały np. dominacji, czy raczej pod- i u-ległości (także w sferze tzw. przemocy symbolicznej) w relacjach interpersonalnych (często przyjęte za oczywiste kulturowo z racji bycia kobietą lub bycia mężczyzną)66. Można zaryzykować stwierdzenie, iż pedagodzy, których asymilacja archetypów Animy i Animusa przybiera postać polaryzacji, w przestrzeni działań pedagogicznych potrzebują czegoś, co będzie tegoż kompensacją (zazwyczaj nieświadomie, ponieważ ich działania dla nich samych są nieczytelne). Stąd ryty oporu - podkreślane przez pedagogikę krytyczną - mają swoje uzasadnienie lub stają się bezzasadne w przestrzeni działań pedagogicznych. Z drugiej strony jeśli chodzi o „dojrzałość” rytów oporu, tych, które wpisują się w transgresyjność w drodze ku szeroko rozumianej emancypacji, przyjmuję, iż zależą od „dojrzałości” nieświadomego wymiaru męskości i żeńskości pedagogów (androgyniczność, ale także konstruktywne cechy „wiecznego chłopca” i „wiecznej dziewczynki”, „syna matki” i „,córki ojca”).

Przyjmując hipotezę, że spolaryzowane formy asymilacji archetypowych męskich i żeńskich wymiarów w rozwoju indywidualnej psyche pedagoga mogą nie pozwalać lub ograniczać wejście na drogę ku świadomości krytycznej, ku meta-

66 Nieświadomi swych cech płciowych pedagodzy/nauczyciele są obecni w szkole, która na zasadzie foucaultowskiej wiedzy-władzy uznaje „na powierzchni” pewne ryty oporu, ale „od wewnątrz" podtrzymuje tradycję, którą opór tylko wzmacnia. 
-dyskursywnemu rozumieniu własnego działania pedagogicznego, jedne z pytań, otwierających horyzont możliwych badań jakościowych, brzmią:

- jakie są rytualne oznaki nie-zasymilowanego pierwiastka żeńskiego i męskiego w przestrzeni działań pedagogicznych?

- co i przez kogo w strukturze instytucji pedagogicznych jest „ukrywane” (kompensowane) i w jaki sposób?

- jakie są kulturowe strategie podtrzymujące spolaryzowane formy archetypowych wymiarów męskości i kobiecości w tworzeniu wiedzy pedagogicznej (np. w edukacji na szczeblu wyższym)?

Wiedza pedagogiczna jest tworzona w taki sposób i taką też się ją posiada, w jaki sposób się myśli. A myślimy z perspektywy tego, w czym jesteśmy. Wykroczyć poza tę całość, zobaczyć jej z zewnątrz nie możemy w żaden sposób. Tworzona wiedza pedagogiczna „w polu praktyki i dla praktyki” może być niespójna, niewyrażalna językowo, niepewna i nieprzystająca do rzeczywistości - a jednak będzie ona zawsze wiedzą konkretnego nosiciela. Kreśląc możliwą perspektywę badawczą, ważne jest zatem to,

- w jakim kontekście doświadczeń życiowych jest tworzona wiedza pedagogiczna?

- w jakim języku, a może raczej, w jakich językach?

- co jest jej "ukrytym programem" i co w nim zostało „ukryte”?

- co dzieje się z wiedzą, jeśli charakteryzuje ją „skrytość” w postaci polaryzacji archetypowych wymiarów męskości i żeńskości?

To tylko jedne z niektórych możliwych problemów badawczych, które same narzucają się wówczas, gdy myśli się o poszerzeniu rozumienia źródeł tworzenia pedagogicznej wiedzy poprzez ich odkrywanie z perspektywy archetypowych wzorców w rozwoju indywidualnej $p$ syche. $Z$ drugiej strony tak zakreślony przedmiot badań oferuje możliwość krytycznego myślenia w dochodzeniu do ustalenia i zrozumienia owych źródeł wiedzy pedagogicznej dla tworzącego tę wiedzę i rodzajów relacji, w jakie wchodzi z samym sobą i z innymi.

Widzę także możliwość zastosowania teorii archetypów w teorii pedagogicznej jako nie tylko kwestii poszerzenia języka opisu wybranych zagadnień pedagogicznych, ale także jako kwestii praktycznych rozwiązań, np. w diagnozie profilu osobowości pedagoga według archetypowego wymiaru męskości i kobiecości w ich uwarunkowaniach kulturowych.

Choć każdy z nas jest sternikiem na własnym okręcie, to jednak nie ulega wątpliwości, że sztuki pływania nie uczymy się zupełnie sami. Pomaga nam w tym i natura, i inni ludzie, którzy w tej sztuce "jakoś" się obyli. Stąd cały wywód warto zamknąć koronnym pytaniem, które brzmi - dość prosto, ale zazwyczaj to, co proste, jest też i najtrudniejsze w życiu i do przeżycia - jak w toku kształcenia, a dalej w trakcie pracy zawodowej, wspomagać pedagogów „w docieraniu” do własnej sfery archetypowych wymiarów męskości i kobiecości, by tworzona 
przez nich wiedza pedagogiczna była wiedzą odkrywającą przed nimi sens działania - ten jawny i ukryty, ale już po jego rozjaśnieniu?

\section{Summary}

Creation of pedagogical knowledge from the perspective of archetypal dimensions of femininity and masculinity

This article mostly focuses on answering the question: „Who creates what knowledge in pedagogical practice?" In search of an answer to this question, it was assumed that there existed a relationship between the archetypal dimension of femininity and masculinity in the development of the individual psyche and the type, structure and function of the pedagogical knowledge created, which involves three aspects: it is always anthropological, axiological and teleological knowledge and knowledge which "works in practice". The archetypal gender of those creating pedagogical knowledge, according to Jungian and post-Jungian psychology - is rooted in the unconsciousness - as real as the consciousness with which the process of knowledge creation is usually associated with. The method of assimilating feminine and masculine features of the individual psyche development forms a deep layer of pedagogical knowledge with overlaps on the tangible reality of pedagogical actions - on the extra- and interpersonal relations (as well as on intropersonal ones). The assimilation complexities - usually set in cultural patters - may consolidate ritual in the area of pedagogical actions - e.g. rituals of submission and submissiveness. The article also presents a hypothesis saying that immature forms of archetypal assimilations of femininity and masculinity prevent or restrict the entry to the road towards critical consciousness of those creating pedagogical knowledge. In conclusions, it was proposed that empirical studies should include the areas determined by the main subject matter presented in the article. 